\title{
Law as Narrative: Narrative Interpretation and Appropriation as an Element of Theft
}

\author{
Steven Cammiss ${ }^{*}$
}

\begin{abstract}
The act requirement for the offence of theft requires that the defendant appropriates property belonging to another. The concept of appropriation, thought by the legislation's drafters to be straightforward, has proved to be difficult to interpret; controversies in the cases and commentary focus upon whether the consent of the owner is relevant to appropriation, and whether the concept includes an adverse interference with property rights. This paper explores these controversies through a different lens; that of law as narrative. Drawing upon law as literature, particularly law and narrative, I argue that narrative interpretations in law result in the creation of 'hard cases', where the application of appropriation, as envisaged by its framers, leads to difficult results. In so doing, I show how the normative syllogism is merely a justification for legal interpretation, with the law best understood in narrative terms. Applying the law is, therefore, not an exercise of correspondence between abstract law and particular facts, but instead an exercise in comparison between different narratives.
\end{abstract}
All persons who blaspheme the gods are liable to be executed Socrates has blasphemed the gods Therefore Socrates is liable to be executed ${ }^{1}$

\section{Introduction}

This paper explores the role of narrative in interpreting law, and in particular appropriation in theft. There has been extensive analysis of the requirement the defendant (D) appropriate property belonging to another, focusing upon whether appropriation should have an expansive or narrow meaning, with two questions emerging: is the victim's consent relevant; and is there an appropriation when ownership of the property transfers to the defendant? My contention is that, despite the doctrinal arguments, theft is interpreted in a narrative form; we understand and interpret theft as narrative. I will approach this in two ways: the extent of narrative reasoning shows how we interpret law as narrative; and focusing upon narrative evaluation evidences the importance of stories within the case as a factor in judgment.

The choice of theft as an illustrative example is deliberate. This appears to be a technical example of statutory interpretation, rather than common law reasoning (which is more aligned with a narrative method). I will show how narrative approaches are adopted when interpreting complex and technical statutory provisions; an activity that, in doctrinal methodologies, is regarded as an exemplar of the application of law to fact (the normative syllogism). This is not to say that all statutory interpretation can be reduced to the narrative method. Jackson, for instance, suggests that narrative interpretation lies behind all decision making, with doctrinal analysis being a justificatory discourse. However, technical and narrative approaches to interpretation can be found in the cases and commentary. I, therefore, make the claim that narrative approaches are adopted alongside others. I also make no claim to primacy; whether technical interpretative methods are

\footnotetext{
${ }^{*}$ Senior Lecturer in Law, Leicester Law School, University of Leicester. I would like to thank Leicester Law School for the provision of study leave and the contributors to the symposium 'What gives meaning to statutory rules and constitutional provisions?', University of Cambridge 11-12 May 2018. The usual disclaimers apply.

${ }^{1}$ B. S. Jackson (1989) Law, Fact and Narrative Coherence, Deborah Charles Publications, at 37.
} 
driven by narrative understandings, or vice versa. This is an empirical question that I cannot address here.

I start with an overview of law and narrative scholarship, the focus of which is upon narrative in law, but moving to examine law as narrative. I then explore doctrinal analysis and Jackson's claim for the primacy of narrative interpretation. Doctrinal analysis adopts the normative syllogism; the application of law to fact. We take a general rule and ask if the facts correspond with this rule. Using Hart's example of 'no vehicles in the park', we assess whether the rule applies by addressing whether an object is a 'vehicle'. Importantly, this reasoning has trouble with 'hard cases', such as emergency vehicles. We can explain 'hard cases' on the basis that the syllogism is a justificatory discourse, and the application of law to fact is actually an exercise in comparing narratives; we compare the narrative of the law with the narrative of the facts.

I then turn to a brief exploration of doctrinal controversies in appropriation; ${ }^{2}$ the cases oscillated between a broad and narrow definition, before settling on the broad interpretation. Of interest to this paper is not the content of these controversies, but on the form of interpretation. I show that the difficulties can be understood if we think of law as narrative; narrative interpretations of the TA have generated 'hard cases'. Further, I will examine how commentary and judgments make use of narrative forms, through the use of vignettes or aphorisms. These interpretative tools draw upon narratives, scripts and schemas. Addressing the difference between a thief or a swindler, or comparing the enemy at the gates with the enemy within, are ways of drawing upon narratives of criminality.

\section{Law and narrative scholarship}

Law and literature scholarship is conventionally separated into two streams: law in literature; and law as literature. ${ }^{3}$ Law in literature explores depictions of law in literary texts, ${ }^{4}$ to understand how law is conceived and how these conceptions shape law. ${ }^{5}$ This includes literary classics ${ }^{6}$ and law in popular culture. $^{7}$ Law as literature, however, adopts inter-disciplinary methods to examine law as text, such as linguistics, conversation analysis, or discourse analysis. ${ }^{8}$ Law as literature questions whether doctrinal analysis is the primary means of interpreting law; multiple methods exist and we adopt these, unconsciously or otherwise. Law and narrative scholarship is an example of law as literature; it explores narrative use in law and interrogates these.

Early law and narrative scholarship explored lay adjudication. Bennett and Feldman argue that jurors adopt a narrative perspective; they do not assess the reliability and credibility of the evidence. Rather, they assess case narratives on two criteria; coherence and plausibility. ${ }^{9}$ Coherence concerns an internal assessment; is there consistency and coherence within the narrative? Plausibility is an external examination where jurors draw upon experience to determine if the narrative is believable. Bennett and Feldman also argue this is a source of bias; marginalised groups' narratives, due to dissimilar life experiences, are regarded as implausible. Pennington and Hastie also argue that

\footnotetext{
2 Theft Act 1968 (hereafter TA), s3.

3 A separation not without its critics; J.B. Baron (1999) 'Law, Literature, and the Problems of Interdisciplinarity' (1999) 108 Yale Law Journal, 1059.

${ }^{4}$ I take a broad approach to the definition of 'text', going beyond orthographic understandings.

${ }^{5} \mathrm{M}$. Aristodemou (2000) Law and Literature: Journeys from Her to Eternity, OUP.

${ }^{6}$ See, for instance, I. Ward (2014) Sex, Crime and Literature in Victorian England, Hart.

${ }^{7}$ M. Valverde (2006) Law and Order: Images, Meanings, Myths, Routledge Cavendish; T. Giddens (eds.) (2015) Graphic Justice: Intersections of Comics and Law, Routledge Cavendish.

${ }^{8}$ See, M. Freeman and F. Smith (eds.) (2013) Law and Language. Current Legal Issues Vol. 15, OUP.

${ }^{9}$ W. L. Bennett and M. S. Feldman (1981) Reconstructing Reality in the Courtroom: Justice and Judgment in the American Courtroom, Tavistock.
} 
jurors' adopt a narrative perspective. ${ }^{10}$ Kjus similarly adopts a narrative framework to explore adjudication; narrative models are used by judges in Norway when determining facts and assessing credibility. ${ }^{11}$

Jackson advances Bennett and Feldman's work; in addition to the narrative in the trial, he points to the narrative of the trial, defined as the 'narrative construction of the pragmatics of the trial. ${ }^{12}$ In other words, we can examine the narratives of the parties and the narrative of the trial process. The narratives in the courtroom result from courtroom interaction and are shaped by legal criteria, which are negotiated amongst the parties. Similarly, advocates utilise rhetorical techniques to influence the jury.

The 'narrative turn' in law is not limited to adjudication. James Boyd White suggests that lawyers are translators, who translate the language of clients into the law. ${ }^{13}$ Cunningham shows how lawyers translate client's stories into a legal narrative. ${ }^{14}$ The result is a distortion, and one that silences the client by removing elements she considers central. I have utilised Labov's 'evaluation model ${ }^{15}$ to explore how prosecutors frame submissions in the mode of trial hearing in magistrates' courts; legal professionals translate narratives into law, distorting the voices of the parties. ${ }^{16}$ Other studies focus on narratives as rhetorical devices; Amsterdam and Bruner explore prominent civil rights cases, showing how the construction of narratives shift over time, either questioning or supporting the status quo. ${ }^{17}$

I want to return to Jackson who applies narrative methods legal interpretation. ${ }^{18}$ In addition to exploring the narratives of and in the trial, Jackson suggests narrative models are utilised when determining the law. Previous studies take the law as given but Jackson argues that narrative models are utilised in determining fact and law. Jackson, therefore, collapses the distinction between law and fact, situating all legal adjudication within semiotics and narratology. Before examining this claim, I will outline the conventional approach to legal analysis; doctrinal exposition.

\section{Conventional understandings of doctrinal analysis}

Legal pedagogy commonly utilises the problem question; a narrative is offered for the application of law to fact. Students are expected to identify the legal issues, determine the law (addressing any ambiguities), apply this to the facts, and then come to a legal conclusion. In this conventional view of legal education, the process develops a number of key skills. Students interrogate a narrative to identify what is legally relevant and ignore superfluous details. They then consider precedent or the principles of statutory interpretation to discover the law. Finally, they determine the outcome by applying law to fact. In short, we train students to 'think like lawyers'.

\footnotetext{
${ }^{10}$ N. Pennington and R. Hastie (1993) 'The Story Model for Juror Decision Making' in R. Hastie (eds.) Inside the Juror: The Psychology of Juror Decision Making, CUP.

${ }^{11}$ A. Kjus (2011) Stories at Trial, Deborah Charles Publications.

${ }^{12}$ B. S. Jackson, above n 1 , at 3.

${ }^{13}$ J. B. White (1990) Justice as Translation: An Essay in Cultural and Legal Criticism, University of Chicago Press.

${ }^{14}$ C. D. Cunningham (1992) 'The Lawyer as Translator, Representation as Text: Towards an Ethnography of Legal

Discourse', 77 Cornell Law Review 1298.

15 W. Labov (1977) Language in the Inner City: Studies in the Black English Vernacular Blackwell.

16 S. Cammiss (2006) “"He Goes Off and I Think He Took The Child": Narrative (Re)Production In The

Courtroom', 17 Kings College Law Journal 71.

${ }^{17}$ A. G. Amsterdam and J. Bruner (2000) Minding the Law: How Courts Rely on Storytelling, and How their Stories Change the Way We Understand the Law - and Ourselves, Harvard University Press.

${ }^{18}$ B. S. Jackson, above n 1.
} 
Central to this framework is the normative syllogism; a deductive process where:

a general rule (the major premise) is applied to the facts of the case (minor premise), these facts having been established as an instance of the facts mentioned in the general rule (or 'subsumed' within it), with the result that the conclusion necessarily follows. ${ }^{19}$

The epigraph, above, is an example of the normative syllogism provided by Jackson. The facts, as determined, are applied to the general rule. If the facts fall within the major premise of the rule, the conclusion follows; in this case, Socrates is liable to be executed. In determining this, we have to address questions such as what did Socrates utter and its legal relevance, that is, 'do they constitute "blasphemy"? 20 Finally, an adjudicator must address whether "the words used by the legislator "cover" this case. ${ }^{21}$

Applying the insights of law and narrative scholarship, there is much that is not considered in this account. Facts are constructed, through interviews with officials, and then reconstructed within the trial. Judges, in espousing the law, use literary and rhetorical techniques to persuade that their analysis is correct. For our purposes, the focus is upon doctrinal analysis; that law can be discovered through precedent or statutory interpretation. Socio-legal approaches question the primacy of doctrine, but doctrinal analysis is the starting point for an alternative understanding; one must know the law, before critiquing its application in context. ${ }^{22}$ It is this question of determining the content of law that is central to our enquiry, and I suggest that we can think of law as narrative. While Jackson notes that while some branches of legal theory recognise that the normative syllogism is a justification for action, the teaching of law proceeds on the basis that this also a description decision making. ${ }^{23}$

\section{Law as narrative}

As noted above, doctrinal analysis privileges the normative syllogism; the application of law to fact. However, Jackson suggests that 'rules are themselves meaningful as socially-constructed narratives, accompanied by particular (and increasingly institutional) forms of approval or disapproval. ${ }^{24}$ The normative syllogism is a 'justification' for decision making, with adjudication informed by subconscious narrative models, of typifications of action, and our reactions to them. ${ }^{25}$ We adjudicate by comparing the case narrative with the narrative of the rule; this is not a 'correspondence' relationship, but 'one of sufficiency of similarity, a question of degree rather than of kind. ${ }^{26}$ Jackson utilises biblical legal examples to illustrate this: 'If a thief is found breaking in, and is struck so that he dies, there shall be no blood guilt for him. ${ }^{, 27}$ Jackson argues these vignettes or parables are used to educate and espouse the law, are almost universal across societies, and allow for normative judgments:

Each narrativised pattern of behaviour is accompanied by some tacit social evaluation: that such behaviour is good, bad, pleasing, unpleasing etc. ${ }^{28}$

\footnotetext{
19 Ibid, at 37.

${ }^{20}$ Ibid.

${ }^{21}$ Ibid.

${ }^{22}$ T. Hutchinson (2017) 'Doctrinal Research: Researching the Jury', in M. Burton and D. Watkins (eds.) Research Methods in Law (2 ${ }^{\text {nd }} \mathrm{Ed}$.), Routledge.

${ }^{23}$ B. S. Jackson, above n1, at 90.

24 Ibid, at 3.

${ }^{25} \mathrm{Ibid}$, at 58 .

${ }^{26} \mathrm{Ibid}$, at 59 .

${ }^{27}$ Ibid, at 98, quoting Exodus 22:1.

${ }^{28}$ Ibid, at 99.
} 
Jackson also examines narratives in the Draft Criminal Code, communicating the law, 'even to lawyers - is aided by narrative illustrations', ${ }^{29}$ while Fletcher's 'patterns of criminality' (manifest criminality, subjective criminality, and subjective criminality), ${ }^{30}$ are narrative models, calling on a "collective image" of a certain type of activity which is criminalised', such as 'the "collective image of acting like a thief." 31

Understanding law as narrative has important implications for the law/fact distinction:

'law' and 'fact' are reduced to the same level - of narrative structures, and the process of application becomes one of comparison. But comparison is necessarily a more loose and opaque process than the deductive aspect of the narrative syllogism. ${ }^{32}$

This illuminates 'hard cases'; a narrative comparison of rule to fact generates a feeling that the rule cannot be applied, as 'a sense of unease remains'. ${ }^{33}$ Taking Hart's 'no vehicles in the park, ${ }^{34}$ and applying this to an ambulance, jars with narrative understandings of the rule. While the rule appears abstract, it is interpreted through a narrative framework, yet the abstract nature of the rule is necessary for legitimating law:

The fact that legal rules have tended to become, in Western legal systems, increasingly abstract and conceptualised tells us more about the pragmatics of rule-telling (its increasingly bureaucratisation and specialisation) than about the nature of rules themselves. ${ }^{35}$

Through the normative syllogism the law presents itself as a bureaucratic language, that dispassionately applies facts to abstract rules, and is disinterested in outcomes.

\section{Interpreting 'appropriation' in doctrinal analysis}

To assess Jackson's claim, I will analyse sections 1 and 3 of the TA (appropriation), for two reasons: 'appropriation' was to be a 'simple' replacement for 'carrying and taking away' under the Larceny Acts, ${ }^{36}$ yet has remained contentious, generating numerous House of Lords (HL) decisions; ${ }^{37}$ and the narrative model seems well suited to precedent, while statutory interpretation seems to better fit the normative syllogism. If statutory interpretation utilises narrative models, this goes some way to validating Jackson's claims. While appropriation was thought to be straightforward, it has proved less so in application, as following the intentions of the Act's proposers would have led to 'hard cases' that do not fit within narrative understandings of theft. However, before exploring the theft as narrative, we should outline the doctrinal controversies.

Section 1(1) of the TA provides:

A person is guilty of theft if he dishonestly appropriates property belonging to another with the intention of permanently depriving the other of it; and "thief" and "steal" shall be construed accordingly.

Appropriation is defined in section 3(1):

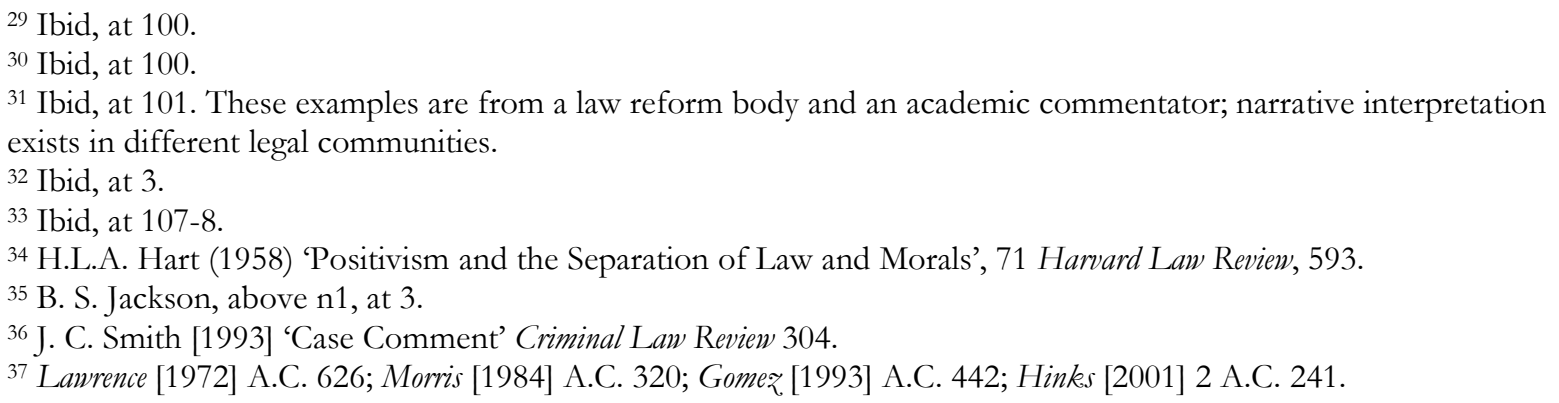


Any assumption by a person of the rights of an owner amounts to an appropriation, and this includes, where he has come by the property (innocently or not) without stealing it, any later assumption of a right to it by keeping or dealing with it as owner.

Appropriation is central to the conduct element of theft; appropriating (assuming the rights of an owner) property belonging to another. In interpreting appropriation, appeal courts have addressed two questions: is the owner's consent relevant; and can appropriation take place if title passes. Lawrence, ${ }^{38}$ Gomer $^{39}$ and Hinks ${ }^{40}$ ruled consent is irrelevant, as is the passing of valid title (Morris ${ }^{41}$ adding that appropriation is an assumption of any of the owners' rights). Gomez rejected the contention in Morris that appropriation includes an adverse interference with the owner's rights. As a result, Hinks ruled that appropriation takes place with the passing of a valid gift, with dishonesty determining the limits of theft.

There is extensive negative commentary on these decisions: they ignore the Act's framers intentions; ${ }^{42}$ create conflict between civil and criminal law; ${ }^{43}$ create 'harmless' offences which lack 'any element of manifest criminality'; ${ }^{44}$ offend against the rule of law, ${ }^{45}$ and confuse the distinction between deception ${ }^{46}$ and theft. ${ }^{47}$ Despite some approval, the underlying view has been hostile, ${ }^{48}$ occasionally to the point of exasperation. ${ }^{49}$ The claim that the decisions ignore the intentions of the legislator is central to this paper.

The TA aimed to simplify the law; the Larceny Acts were complex, relying upon technical and idiosyncratic distinctions. Replacing 'taking and carrying away' with appropriation was hoped to remedy this. ${ }^{50}$ The Criminal Law Revision Committee (CLRC), in proposing the TA, ${ }^{51}$ intended theft to include larceny by taking and carrying away (without consent) and larceny by conversion (which required it be 'without the consent of the owner'). ${ }^{52}$ Similarly, they intended there would be no appropriation if a valid transfer took place. ${ }^{53}$ However, their report was not consulted:

The crux of this case was the decision of the majority not to refer to the Eighth Report of the CLRC. "In my opinion, said Lord Keith, "it serves no useful purpose at the present time to seek to construe the relevant provisions of the Theft Act by reference to [the Eighth Report]." No useful purpose! Except of course that

38 [1972] A.C. 626.

39 [1993] A.C. 442.

40 [2001] 2 A.C. 241.

41 [1984] AC 320.

42 J. C. Smith, above n 36.

${ }^{43}$ A. P. Simester and J. Beatson (1999) 'Stealing One’s Own Property', 115 Law Quarterly Review 372.

${ }^{44}$ A. T. H. Smith (2001) 'Theft or Sharp Practice: Who Cares Now?’ 60(1) Cambridge Law Journal 21, at 22. Also see J.

C. Smith, above n 36 .

${ }^{45}$ S. Shute [2002] 'Appropriation and the Law of Theft', Criminal Law Review 445.

46 The offences of obtaining by deception have been replaced by fraud offences. As the cases and commentary deal with the old offence, I will continue to use the old terminology.

${ }^{47}$ S. Shute and J. Horder (1993) 'Thieving and Deceiving: What is the Difference?', 56(4) Modern Law Review 548, at

553; E. Melissaris (2007) 'The Concept of Appropriation and the Law of Theft' 70(4) Modern Law Review 581.

${ }^{48}$ For a review, see A. L. Bogg and J. Stanton-Ife (2003) 'Protecting the Vulnerable: Legality, Harm, and Theft', 23(3) Legal Studies 402.

49 J. C. Smith [2001] 'Case Comment', Criminal Law Review 162.

${ }^{50}$ Criminal Law Revision Committee Eighth Report (1966) Theft and Related Offences, Cmnd. 2977, HMSO, para 34.

See also M Giles and S. Uglow (1992) 'Appropriation and Manifest Criminality in Theft' 56 Journal of Criminal Law 179 and M. J. Allen and S. Cooper (1992) 'Rethinking Appropriation' 56 Journal of Criminal Law 87.

${ }^{51}$ Criminal Law Revision Committee Eighth Report, above n 50.

$52 \mathrm{~J}$. C. Smith, above n 49.

53 J. C. Smith [1998] 'Case Comment' Criminal Law Review 904. 
it demonstrated conclusively that the decision of the majority flatly contradicted the intention of Parliament. ${ }^{54}$

It appears the courts have ignored the legislators' intentions and overextended the offence. This runs counter to the statutory interpretation principle that offences be interpreted in the defendant's favour. However, in some cases the court was dealing with disreputable conduct, with errors made elsewhere. In Lawrence and Gomez convictions for the s15 offence of obtaining property by deception would be straightforward, but the prosecution chose a theft charge. In Hinks evidence was not put to the jury that suggested the transfer was objectionable, for lack of capacity or undue pressure. Therefore, each court was faced with a choice of doctrinal purity or an unjustified acquittal. In response, the courts engaged in doctrinal gymnastics to ensure conviction; the decisions adopted a narrative interpretation, with a doctrinal justification following. However, narrative interpretations have been used to criticise these decisions, through narratives and parable.

\section{Theft as a narrative concept}

The Act's framers utilised narrative understandings of theft in interpretation, as seen in correspondence between the draftsman and the CLRC:

I trust the Sub-Committee will not agree with Dr [Glanville] Williams when he says... that a person appropriates for himself property of which another person is the owner every time he gratefully accepts a gift or buys an apple. If this is what the words mean, then the whole language of the clause ought to be changed, because one really cannot have a definition of stealing which relies on the word 'dishonestly' to prevent it covering every acquisition of property. ${ }^{55}$

The examples used are commonplace, such as buying gifts or food. They cannot, for the draftsman, satisfy the conduct element of the offence. Similarly, the CLRC noted:

Obtaining by false pretences is ordinarily thought of as different from theft, because in the former the owner in fact consents to part with his ownership; a bogus beggar is regarded as a rogue but not as a thief, and so are his less petty counterparts. To create a new offence of theft to include conduct which ordinary people would find difficult to regard as theft would be a mistake. ${ }^{56}$

This is a demand for fair labelling, framed in narrative terms; bogus beggars are rogues, not thieves. Unlike later examples that use scripts, we are left to create the image of the 'bogus beggar' and contrast that with our everyday understanding of theft; these call on different evaluations in sense making. Later, the CLRC draw upon ordinary people's views and their narrative understandings of these characters.

Turning to the decisions, they use a number of narrative devices (in addition to doctrinal justifications). Lawrence was the first judgment to assess the relevance of the owner's consent. The defendant, a taxi-driver, overcharged a tourist (with a poor grasp of English) by taking money from his opened wallet. A narrative understanding frames the 'appropriation' as an unscrupulous taxi-driver taking advantage of a vulnerable tourist; any consent was not free or informed. Doctrinally, this is obtaining property by deception (an implied representation regarding the correct fare). However, the prosecution proceeded with theft. In addressing consent, the court noted that 'without the consent of the owner' was omitted from the provision, and:

\footnotetext{
${ }^{54}$ J. C. Smith, above n 36, at 305.

55 J. C. Smith, above n 53, at 905.

${ }^{56}$ Criminal Law Revision Committee Eighth Report, above n 50, para 38.
} 
That there was appropriation in this case is clear. Section 3 (1) states that any assumption by a person of the rights of an owner amounts to an appropriation. Here there was clearly such an assumption. ${ }^{57}$

Consent was only relevant to dishonesty. However, as seen above, there was little reason for parliament to include 'without the consent of the owner', given the history of the provision. Faced with a choice of following the legislator's intent, or convicting $\mathrm{D}$, the court chose conviction. There is little analysis of appropriation's meaning, whether as an everyday concept or technical legal definition. This is evidence of a narrative model, a paradigm case of wrongdoing; D appropriates the tourist's money because his actions were wrong, and legal technicalities should not interfere. The court came to a normative judgment, and the reference to the absence of 'without the consent of the owner' is a doctrinal justification.

In Morris, Lord Roskill, stating that appropriation includes an adverse interference with the owner's rights, employed the honest shopper's supermarket actions:

When the honest shopper acts as I have just described, he or she is acting with the implied authority of the owner of the supermarket to take the goods from the shelf, put them in the trolley, take them to the checkpoint and there pay the correct price, at which moment the property in the goods will pass to the shopper for the first time. ${ }^{58}$

This is a mundane script of selecting goods, putting them in a receptacle and effecting payment. To suggest these actions form the conduct element of theft is to question if the majority in Lawrence have taken leave of their senses. Similarly, Lord Roskill draws upon the prankster who, 'with some perverted sense of humour', switches price labels. ${ }^{59}$ The narrative of the prankster is interesting; the motive suggests she may create problems, but the behaviour is not criminal. However, in Dobson, this was challenged in doctrinal terms:

The goods on the shelves belong to the supermarket. They continue to belong to the supermarket until paid for by a customer: Lacis v. Cashmarts [1969] 2 Q.B. 400. The customer assumes some of the rights of an owner when he takes them into his (or her) possession and exercises control over them by putting them in a basket or trolley. The customer, not intending to return the goods to the supermarket, intends to deprive the supermarket of the goods permanently. In the ordinary case the customer will honestly intend to pay the marked price for the goods at the cash desk, so no offence of theft will be committed. But a customer who dishonestly intends not to pay the marked price will be guilty of theft, at the time of dishonest appropriation. On this analysis it is irrelevant that the supermarket displays the goods for sale and invites, perhaps even tempts, customers to put them in their baskets or trolleys. The acid test is whether when doing so the customer acts honestly or dishonestly. ${ }^{60}$

The everyday shopper narrative is translated into a legal narrative focusing on ownership, an intention to permanently deprive, and dishonesty; the honest shopper has nothing to fear. Doctrinally, however, this is problematic; it removes any manifest criminality and theft is, therefore, a 'thought crime'. ${ }^{61}$ However, when interpreting Dobson in narrative terms the conclusion becomes understandable. The victim sold jewellery to a fraudster who offered a stolen cheque, which was not honoured. The victim claimed on his insurance, which covered losses occasioned by theft, but not deception, leading to an argument as to whether it applied. In narrative terms, we have a private seller conned by an (unknown) rogue with a company refusing to compensate the loss. This script calls upon images of a large corporation relying upon terms and conditions to escape their moral (if not legal) obligations. This is a 'hard case' that does not fit with the narrative interpretation of theft in Morris.

\footnotetext{
57 [1972] AC 626, at 632.

58 [1984] A.C. 320 , at 332.

${ }^{59}$ Ibid.

${ }^{60}$ [1990] 1 QB 274, at 287.

61 A. T. H. Smith, above n 44.
} 
Gomez, had to decide to follow Lawrence or Morris. D, a shop assistant, persuaded a manager that a stolen cheque was 'as good as cash', when he knew this was false. The cheque was not honoured, after the purchaser made off. This is clearly obtaining property by deception, yet the prosecution proceeded with theft. The court was faced with convicting a rogue or affirming legislative intentions. Unsurprisingly, the HL followed Lawrence; the goods were appropriated, despite the owner's consent. This was taken to its logical conclusion in Hinks; the recipient of a valid gift will be guilty of theft if dishonest. Despite evidence the gift was compromised for undue influence or lack of capacity, the trial judge ruled consent was irrelevant to appropriation; the issue, therefore, was not put to the jury. Consequently, the HL assumed the gift was valid and to accept it was an appropriation:

\begin{abstract}
My Lords, for my part the position would have been different if I had any lurking doubt about the guilt of the appellant on the charges for which she was convicted. In the light of a fair and balanced summing up and a very strong prosecution case, the jury accepted the prosecution case and rejected the appellant's account as untruthful. They found that she had acted dishonestly by systematically raiding the savings in a building society account of a vulnerable person who trusted her. ${ }^{62}$
\end{abstract}

In noting that $\mathrm{D}$, 'systematically raiding the savings... of a vulnerable person who trusted her', Lord Steyn passed moral judgment on Hinks. There is no place for doctrinal purity, only a comparison of narratives. The defence provided narratives that would lead to injustice due to a wide definition of appropriation: a gift made when the donor was mistaken as to the recipient's achievements; D sells a painting to a purchaser who thinks it a priceless worth of art and D knows this is false; and an employee and employer agree a severance package where facts (not known to the employer) exist that could justify the employee's dismissal without compensation. Lord Steyn responded with, 'I am quite unpersuaded that the House overlooked the consequences of its decision'. ${ }^{63}$ Furthermore:

If the law is restated by adopting a narrower definition of appropriation, the outcome is likely to place beyond the reach of the criminal law dishonest persons who should be found guilty of theft. The suggested revisions would unwarrantably restrict the scope of the law of theft and complicate the fair and effective prosecution of theft. ${ }^{64}$

In his dissent, Lord Hutton drew upon the example of a mechanic who changes engine oil at the owner's request. To call this appropriation is:

an absurdity, even when one takes into account that some of the absurd results can be avoided by other parts of the definition of theft. The mechanic is not assuming any right he is merely carrying out the instructions of the owner. The person who accepts a valid gift is simply conforming to the wishes of the owner. ${ }^{65}$

While coming to different conclusions, both judges adopt narrative reasoning. Lord Steyn draws upon the case narrative, classifying this as a narrative of exploitation. Lord Hutton, however, narrates results of a broad interpretation, seeing these as everyday, honest, exchanges. Narrative interpretation is not a question of correspondence, but of comparison. The court compares narrative examples, rich in normative judgments, to interpret appropriation. As an exercise in comparison, rather than correspondence, we can see the route to different conclusions.

Academic commentary also uses vignettes and aphorisms to interpret appropriation; aphorisms provide a pithy means of evaluating decisions in a similar manner to narratives, calling upon pre-

62 [2001] 2 A.C. 241 , at 253.

${ }^{63} \mathrm{Ibid}$, at 252.

${ }^{64}$ Ibid.

${ }^{65} \mathrm{Ibid}$, at 268. 
existing scripts and schema. To illustrate this, I will provide a number of examples. The most common example is, once again, the supermarket shopper. The shopper reappears in many guises, such as the shopper who: never intends to pay; ${ }^{66}$ accidentally knocks goods off the shelf; ${ }^{67}$ mischievously switches labels; ${ }^{68}$ suspiciously looks at goods in a shop window; ${ }^{69}$ dishonestly switches labels intending to purchase at a lower price; ${ }^{70}$ conceals goods in his jacket; ${ }^{71}$ offers a worthless cheque; ${ }^{72}$ falsely claims they are entitled to a discount. ${ }^{73}$ There is a narrative richness in these, despite their brevity. They allow for moral and normative comparisons rather than correspondence with a rule. Is surreptitiously concealing goods similar to using a worthless means of payment or switching labels for dishonest gain? Do we differentiate between the clumsy shopper who knocks over goods from the prankster who switches labels for amusement?

Other narratives are also offered: the overcharging lawyer ${ }^{74}$ or tradesman $;{ }^{75}$ purchasing art thought be a masterpiece when the owner knows this is false; ${ }^{76}$ selling goods knowing they are not suitable for the buyer's purposes; ${ }^{77}$ the recipient of an underserved gift; ${ }^{78}$ and inserting a banana into the exhaust of a car. ${ }^{79}$ The following is typical of the use of such vignettes:

The lawyer who overestimates the value of his services steals his fee, if a jury is satisfied only that he was dishonest - a conclusion to which a jury, envisaging lawyers generally as sharks, might not be reluctant to come. There is no longer any need to prove any deception. ${ }^{80}$

These examples, fictional and real, are used to highlight the effect of a particular interpretation. They draw upon a stock of common knowledge, understood in narrative form, to interpret legal provisions. Aphorisms perform a similar role, although not, on the face of it, through narrative. Aphorisms are offered in assessing the difference between theft and deception offences. A wide definition of appropriation collapses the distinction between theft and deception. While commentary focuses upon fair labelling, underlying this concept is narrative interpretation; the labels attached should reflect common understandings of offences. Clarkson, for instance, draws a clear moral distinction between theft and deception in their paradigmatic forms. Theft involves a surreptitious or forcible taking, while obtaining by deception involves a "voluntary" handover of the property. ${ }^{81}$ The reference to paradigmatic forms relies upon narrative interpretation; they are illustrative evaluative examples. 'The paradigmatic theft involves a surreptitious or forcible taking, while deception offences involve a confrontation and a participation by the victim in the loss of the property. ${ }^{82}$ These stock narratives draw upon frameworks that mean we evaluate behaviour differently. 'Putting it metaphorically, whereas the thief makes war on social practice from the outside, the deceiver is the traitor within. ${ }^{83}$ This aphorism draws upon narratives to emphasise the evaluative distinctions between the offences; the thief 'bypasses... social practice' in an external

${ }^{66}$ C. M. V. Clarkson (1993) 'Theft and Fair Labelling' 56(4) Modern Law Review 554.

${ }^{67} \mathrm{~J}$. C. Smith, above n 36; E. Melissaris, above n 47.

${ }^{68}$ E. Melissaris, above n 47.

${ }^{69}$ Ibid.

${ }^{70}$ M. Giles and S. Uglow, above n 50.

${ }^{71}$ Ibid.

${ }^{72}$ Ibid.

73 S. Shute, above n 45.

${ }^{74}$ A. T. H. Smith, above n 44.

75 S. Gardner (1993) 'Appropriation in Theft: The Last Word?' 109 Law Quarterly Review 194.

76 A. P. Simester and J. Beatson, above n 43.

77 S. Shute, above n 45.

${ }^{78}$ Ibid.

${ }^{79}$ M. J. Allen and S. Cooper, above n 50.

${ }^{80} \mathrm{~J}$. C. Smith, above n 53, at 905.

${ }^{81}$ C. M. V. Clarkson (1992) 'Authorised Acts and Appropriation', 55(2) Modern Law Review 265, at 267.

${ }^{82}$ C. M. V. Clarkson, above n 66, at 555.

${ }^{83}$ S. Shute and J. Horder, above n 47. 
attack on property rights, while the deceiver works from the inside to undermine property rights, as the wrong 'centres on the abuse of what should have been an autonomy enhancing transaction'. ${ }^{4}$

However, not all agree upon a clear difference. Gardner, argues that deception offences, with a higher maximum sentence, are aggravated forms of theft, reflecting the 'additional injury' of 'a feeling of intellectual vulnerability. ${ }^{85} \mathrm{Bogg}$ and Stanton-Ife support Hinks and the wide interpretation, as theft is best understood as a 'family resemblance' concept:

An alternative possibility is that the ordinary language concept of theft takes the form of a family resemblance idea in Wittgenstein's image. Instead of producing something further to all that we call theft, we should say that the phenomena it picks out have no one thing in common which makes us use the same word for all; like a family, the Wittgensteinian would say, they are related to one another in different ways. And, she would add, it is because of this relationship, or these relationships, that we call them all theft. ${ }^{86}$

Theft cannot be reduced to common terms or concepts. Whether transfers are voluntary, consensual etc. is not the key to understanding theft. Rather, there are different and overlapping ideas about theft, which include 'exploitation and its manifold forms, such as coercion, manipulation and, indeed, deception ${ }^{37}$ This account challenges the moral distinction between theft and deception. Their narrative interpretation of theft draws upon many practices, with no real distinction between consensual or non-consensual takings; they are all of the theft 'family'. Bogg and Stanton-Ife draw upon Wittgenstein's example of 'a game' as a family resemblance concept. There are no clear characteristics central to the concept. Each game shares features with others, but not all games. Rather, they are 'grouped together by a whole series of overlapping similarities. ${ }^{98}$ This echoes Jackson's model of narrative interpretation; comparing facts with a narrative interpretation of law. Indeed, Jackson specifically draws comparisons between narrative interpretation and Wittgenstein's 'family resemblance' model. ${ }^{89}$ If we understand theft as a 'series of overlapping similarities', then assessing if an action is theft requires comparing the facts with our many, but similar, narrative constructions of theft.

Turning to Gardner's defence of the expansive interpretation, he asks, '[i]s theft a rip-off?" ${ }^{90}$ For him, the requirement of adverse interference with the owner's rights in Morris is 'a polite expression' to denote a 'rip-off. ${ }^{91}$ This 'pejorative connotation... invites the jury to let us have the benefit of their instincts; lawyers might not, but surely jurors can recognize a rip-off when they see one. ${ }^{92}$ In the same way we trust jurors to interpret dishonesty or gross negligence, Gardner notes the broad interpretation allows jurors to adjudicate through evaluative judgments rather than the normative syllogism:

Again, lawyers would want to deal with this point under the rubric of whether the consent was vitiated; but jurors might be left simply to follow their instincts. So sometimes they might feel that someone had been ripped off despite the fact that he had consented to the assumption of his rights. This is probably true of Lawrence itself. A taxi-driver took money far in excess of his due fare from the wallet of his passenger, with the latter's permission. The passenger was an Italian student, just arrived in London and speaking very little

${ }^{84}$ Ibid.

85 S. Gardner, above n 75, at 198.

86 A. L. Bogg and J. Stanton-Ife, above n 48.

${ }^{87} \mathrm{Ibid}$, at 405. Emphasis in original.

88 Ibid.

${ }^{89}$ B. S. Jackson, above n1, at 170.

${ }^{90}$ S. Gardner (1990) 'Is Theft a Rip Off?', 10(3) Oxford Journal of Legal Studies 441.

${ }^{91}$ Ibid, at 445 .

92 Ibid. 
English. He was so disoriented that the taxi-driver's action in taking the money from him was little different from taking candy from a baby - a rip-off, whether he consented or not. ${ }^{93}$

This is a narrative interpretation of Lawrence; the taxi-driver stole the money, just as if he stole 'candy from a baby'. While Gardner suggests that this means of adjudicating is familiar to jurors, the central argument of this paper is that it is also familiar to lawyers. Indeed, Gardner himself reconciles Lawrence and Morris by reference to a narrative understanding of the cases that emphasise their similarities, rather than their differences.

\section{Conclusions}

In this paper I utilised a law as literature framework, in particular law as narrative, to examine statutory interpretation in case judgments and commentary. There is evidence of narrative interpretation permeating decision making, on two levels: the use of narrative vignettes and aphorisms; and a narrative construction of the cases. While the framers of the TA believed that sections 1 and 3 would simplify the law, 'hard cases' and an extensive interpretive exercise have resulted. This results from an implicit narrative interpretation of the TA, while narrative methods have been used in an attempt to settle the debate. However, narrative interpretations are based upon comparison, not correspondence. We see multiple narrative understandings of theft which help explain the disagreements outlined. For instance, for some, deceivers are 'the enemy within', while for others they engage in aggravated theft.

It is important to recognise the limitations of my assertions. I am attracted to Jackson's claim that narrative interpretation is the basis of all legal adjudication, with doctrinal discourse justifying (and some may say obscuring the reasons for) decisions. However, this is an empirical question of what influences decision making. The texts examined here undoubtedly leave a trace of the evaluative processes that produced them, but it is merely that; a trace. Further, lawyers, as an interpretative community, must have some (conscious) fidelity to law. This may be a surface discourse that hides deeper structures that inform decisions, but even as a surface discourse it must influence behaviour, such as the selection of legally relevant details. These are questions for another day, hence my claim that narrative interpretations are an important part of legal adjudication, if not the primary means.

What does this mean for statutory interpretation? It should alert us to lawyers' justificatory claims; law is a specialised discourse that disinterestedly applies law to fact. If lawyers do understand abstract rules in narrative forms, with the normative syllogism merely a justificatory discourse, then interpretation in law shares many of the features of interpreting texts in other areas of life. Indeed, if Jackson's claim that narrative interpretation is universal is true, then interpreting the law is not such a specialised activity. Instead, the specialism in the profession is the art of justification. Similarly, the claim that law is disinterested in outcomes is problematic if law is narrative; adjudicators are drawing upon evaluative frames when discovering the law, as are commentators when they critique judgments. If this is the case, further work should focus upon these evaluative narrative frames, to examine the normative assumptions within. Narrative analysis is equipped for this, but it is a task for another day.

\footnotetext{
93 Ibid, at 446.
} 